\title{
PERAN MUSIK KLASIK BARAT DALAM PENINGKATAN SEKRESI SALIVA PASIEN GERIATRI DENGAN KONDISI XEROSTOMIA
}

\author{
Intan Kemala Dewi \\ Bagian Ilmu Penyakit Mulut, Fakultas Kedokteran Gigi, Universitas Mahasaraswati Denpasar \\ E-mail: intan.kd36@gmail.com
}

\begin{abstract}
Xerostomia or dry mouth is one of the complaints in oral cavity, which associated with reduced salivary flow. Many issues will appear in people with xerostomia, such as dry mouth mucosa that can cause irritation in the oral cavity, difficulty speaking, burning mouth, taste disturbance, increased tooth decay and plaque, halitosis, changes in soft tissue, inflammation of periodonsium, and problems of prosthesis. Music can be used as an alternative in improving saliva secretion. Music that is formed through a slow tempo, repetitive rhythm, and gentle contour will provide silent and relax atmosphere. The nerve that dominates the state of calm and relaxed is the parasympathetic nervous system which supplies the saliva glands, and causes the expenditure watery saliva in large amount and enzyme rich. There were increasing saliva secretion in the result of this research, where the mean of salivary secretion in western classical music group before treatment was $0.087 \pm 0.007 \mathrm{ml} /$ minute, and after treatment was $0.204 \pm 0.13 \mathrm{ml} / \mathrm{minute}$. It is recommended to patients with xerostomia, especially in the elderly to listen the western classical music, which can make our mind relax and also increase the salivary secretion.
\end{abstract}

Keywords : Music, salivary secretion, xerostomia

\section{PENDAHULUAN}

Salah satu keluhan di rongga mulut yang berhubungan dengan berkurangnya aliran saliva adalah xerostomia, yang secara harfiah berarti mulut kering. Xerostomia umumnya berhubungan dengan berkurangnya aliran saliva dari kelenjar saliva. Adakalanya jumlah atau aliran saliva normal tetapi seseorang tetap mengeluh bahwa mulutnya kering. Keadaan ini dapat terjadi pada kondisi akut atau kronis, sementara atau permanen dan kurang atau agak sempurna. Xerostomia diperkirakan terjadi pada berjutajuta masyarakat Amerika dan penelitian menemukan kejadian ini pada $17-29 \%$ populasi sampel, berdasarkan laporan perorangan atau pemeriksaan laju aliran saliva. ${ }^{1}$

Timbulnya keluhan mulut kering tergantung dari penyebabnya, seperti terapi radiasi pada daerah leher dan kepala, Sjogren Sindrom, penyakit sistemik, efek samping obat-obatan, stres, dan usia lanjut. ${ }^{2}$ Keluhan mulut kering pada usia lanjut disebabkan adanya perubahan kelenjar saliva berupa atropi sesuai pertambahan umur sehingga terjadi penurunan produksi saliva dan sedikit perubahan komposisinya. Proses penuaan (aging) menyebabkan terjadi perubahan dan kemunduran fungsi kelenjar saliva. Hilangnya kelenjar parenkim akan digantikan oleh jaringan lemak dan jaringan ikat, lining sel ductus intermediate mengalami atropi sehingga terjadi pengurangan jumlah aliran saliva. ${ }^{3,4}$ Selain itu, penyakit-penyakit sistemik yang diderita pada usia lanjut dan obat-obatan yang digunakan untuk perawatan penyakit sistemik dapat menyebabkan pengaruh mulut kering pada usia lanjut. ${ }^{5}$ Diperkirakan 30\% dari pasien yang berusia 65 tahun dan yang lebih tua menderita kelainan ini.

Mulut kering yang disebabkan oleh adanya suatu pengobatan merupakan penyebab yang paling umum ditemukan. Sebagian besar pasien usia lanjut pernah mengalami perawatan dengan menggunakan obat yang dapat menyebabkan hipofungsi saliva. ${ }^{6}$ Prevalensi dari xerostomia meningkat sampai $60 \%$ pada pasien yang menerima pengobatan jangka panjang obat psikiatri, anti hipertensi atau kelainan ginjal. ${ }^{7}$

Dewasa ini belum ada satupun terapi xerostomia yang memadai, tetapi perawatan secara komprehensif dapat diusahakan untuk meningkatkan kenyamanan dan fungsi rongga mulut pasien serta mencegah meluasnya kerusakan gigi. Perawatan yang dapat dilakukan adalah dengan cara merangsang sekresi saliva, baik dengan cara mekanis seperti mengunyah makanan keras atau permen karet, cara kimiawi seperti rangsangan rasa asam, manis, asin, pahit, pedas, ataupun dengan perangsangan neuronal melalui sistem saraf otonom, baik simpatis maupun parasimpatis. ${ }^{8}$

Perawatan dengan menggunakan obat-obatan yang dapat merangsang sistem saraf parasimpatis sudah banyak digunakan, tetapi obat-obatan tersebut memiliki kontra indikasi dan efek samping. Pilocarpine memiliki kontra indikasi pada pasien asma, narrow-angel glaucoma atau iritis. Selain itu, pilocarpine juga memiliki efek samping meningkatkan ekskresi keringat, gangguan gastrointestinal, hipotensi, rhinitis, diare dan gangguan penglihatan. Selain pilocarpine, perawatan xerostomia dengan menggunakan cevimeline dan anethole trithione juga memiliki berbagai kontra indikasi dan efek samping. Penggunaan saliva buatan dinilai kurang menyelesaikan masalah karena belum ada satupun larutan yang memiliki komposisi yang persis sama dengan saliva. Saliva buatan juga tidak memiliki durasi yang lama oleh karena terus-menerus ditelan. ${ }^{9}$

Salah satu dari jenis musik yang biasa dipakai sebagai terapi dalam bidang kesehatan adalah musik klasik. Penelitian yang dilakukan oleh Hasegawa $(2010)^{10}$, musik klasik dapat meningkatkan sekresi 
saliva pada partisipan dengan usia rata-rata 25 tahun, yang sebelumnya diberikan stressor. Jumlah sekresi saliva cenderung meningkat melalui sistem saraf parasimpatis. Dinyatakan bahwa corticotrophin releasing hormone (CRH) mengaktifkan sistem sympathetic-adrenal medullary. Dengan pemberian musik akan menghambat pelepasan $\mathrm{CRH}$ oleh hipotalamus, sehingga sistem saraf simpatis menjadi tidak aktif. Tujuan penelitian ini adalah untuk mengetahui apakah musik klasik barat dapat meningkatkan sekresi saliva penderita xerostomia usia lanjut.

\section{BAHAN DAN METODE}

Instrumen penelitian yang digunakan antara lain pot saliva, spuit injeksi $1 \mathrm{cc}, C D$ musik klasik Mozart dengan judul "Greatest Hits Mozart" produksi Sony Classical, CD Player, Speaker aktif (Beta 3), Mixer (Behringer) sebagai alat penyambung antara $C D$ player dan speaker aktif, Stopwatch, Soundlevel meter (Lutron SL-4001, Taiwan) untuk mengukur kekerasan suara, alat tulis dan kamera.

Sebelum penelitian dilakukan, sampel tidak diperkenankan untuk makan, minum maupun membersihkan rongga mulutnya selama 30 menit. Selama pengumpulan saliva, sampel tidak diperkenankan untuk berbicara, menggerakkan lidah, mengunyah dan melakukan gerakan penelanan. Setelah memasuki ruang studio musik Fakultas Kedokteran Gigi Universitas Mahasaraswati Denpasar, sampel disilakan duduk dikursi yang telah tersedia. Segera setelah sampel duduk yang nyaman dengan sandaran tegak, dilakukan pengumpulan saliva menggunakan metode spitting, dengan cara sebagai berikut.

Sampel duduk dengan tenang dan diam sambil menundukkan kepala dan tangan kanan memegang pot saliva. Sampel diinstruksikan untuk tidak menelan selama prosedur berlangsung. Sesaat sebelum prosedur pengumpulan dimulai, sampel diharuskan menelan semua sisa saliva yang ada di rongga mulut. Saliva dibiarkan mengumpul di dalam rongga mulut dan setiap menit saliva yang sudah terkumpul dikeluarkan ke dalam pot saliva. Pengumpulan saliva dilakukan selama 3 menit. Jumlah saliva yang terkumpul dalam pot saliva, kemudian diukur menggunakan spuit injeksi dan dicatat sebagai observasi sekresi saliva sebelum mendengarkan musik klasik barat.

Setelah saliva terkumpul, sampel diperdengarkan musik klasik Mozart selama 13 menit yang diputar menggunakan $C D$ Player dengan posisi sampel duduk yang nyaman. 3 menit terakhir saat mendengarkan musik, sampel kembali disilakan untuk mengumpulkan salivanya dengan menggunakan metode spitting, seperti penjelasan sebelumnya.

\section{HASIL DAN PEMBAHASAN}

Analisis efek perlakuan diuji berdasarkan rerata sekresi saliva antara sebelum dengan sesudah diberikan perlakuan. Hasil analisis kemaknaan dilakukan dengan uji Wilcoxon Signed Ranks disajikan pada Tabel 1 berikut.
Tabel 1 Perbedaan rerata sekresi saliva antara sebelum dengan sesudah mendengarkan musik klasik barat

\begin{tabular}{|c|c|c|c|c|}
\hline \multicolumn{2}{|c|}{ Sekresi Saliva (ml/menit) } & \multirow{2}{*}{$\begin{array}{c}\text { Beda } \\
\text { Rerata }\end{array}$} & \multirow{2}{*}{$Z$} & \multirow{2}{*}{$p$} \\
\hline Pre & Post & & & \\
\hline $0,087 \pm 0,007$ & $0,204 \pm 0,13$ & 0,117 & $-2,90$ & 0,004 \\
\hline
\end{tabular}

Tabel 1 di atas menunjukkan bahwa rerata sekresi saliva sebelum perlakuan adalah 0,087 $\pm 0,007$ $\mathrm{ml} / \mathrm{menit}$, rerata sesudah perlakuan adalah $0,204 \pm 0,13$ $\mathrm{ml} / \mathrm{menit}$. Analisis kemaknaan dengan uji Wilcoxon Sign Rank menunjukkan bahwa nilai $Z=-2,90$ nilai $p=$ 0,004 . Hal ini berarti bahwa terjadi peningkatan sekresi saliva setelah mendengarkan musik klasik barat secara bermakna $(\mathrm{p}<0,05)$.

Mekanisme kerja musik dalam meningkatkan sekresi saliva berkaitan dengan fungsi-fungsi fisiologis tubuh terutama berkaitan dengan sistem pendengaran, sistem saraf pusat dan sistem saraf tepi. Musik sebagai gelombang suara diterima dan dikumpulkan oleh daun telinga masuk ke dalam meatus akustikus eksternus hingga membrana timpani. Telinga mengubah gelombang suara di udara menjadi gerakan-gerakan berosilasi membrana basilaris yang membengkokkan pergerakan maju mundur rambut-rambut di sel reseptor. Perubahan bentuk mekanis rambut-rambut tersebut menyebabkan pembukaan dan penutupan (secara bergantian) saluran di sel reseptor, yang menimbulkan perubahan potensial berjenjang di reseptor, sehingga mengakibatkan perubahan kecepatan pembentukan potensial aksi yang merambat ke otak. Dengan cara ini, gelombang suara diterjemahkan menjadi sinyal saraf yang dapat dipersepsikan oleh otak sebagai sensasi suara. ${ }^{11}$

Setelah melalui sistem pendengaran, impulsimpuls saraf dihantarkan melalui nervus VIII (vestibulocochlearis) menuju otak. Impuls ini masuk melalui serabut saraf dari ganglion spiralis Corti menuju ke nukleus koklearis dorsalis dan ventralis yang terletak pada bagian atas medula. Pada titik ini semua serabut sinaps dan neuron tingkat dua berjalan terutama ke sisi yang berlawanan dari batang otak dan berakhir di nukleus olivarius superior. Setelah melalui nukleus olivarius superior, penjalaran impuls pendengaran berlanjut ke atas melalui lemnikus lateralis, kemudian berlanjut ke kolikulus inferior, tempat semua atau hampir semua serabut ini berakhir. Selanjutnya, jaras berjalan ke nukleus genikulatum medial, tempat semua serabut bersinaps. Akhirnya, jaras berlanjut melalui radiasio auditorius ke korteks auditorik, yang terutama terletak pada girus superior lobus temporalis. ${ }^{12}$ 


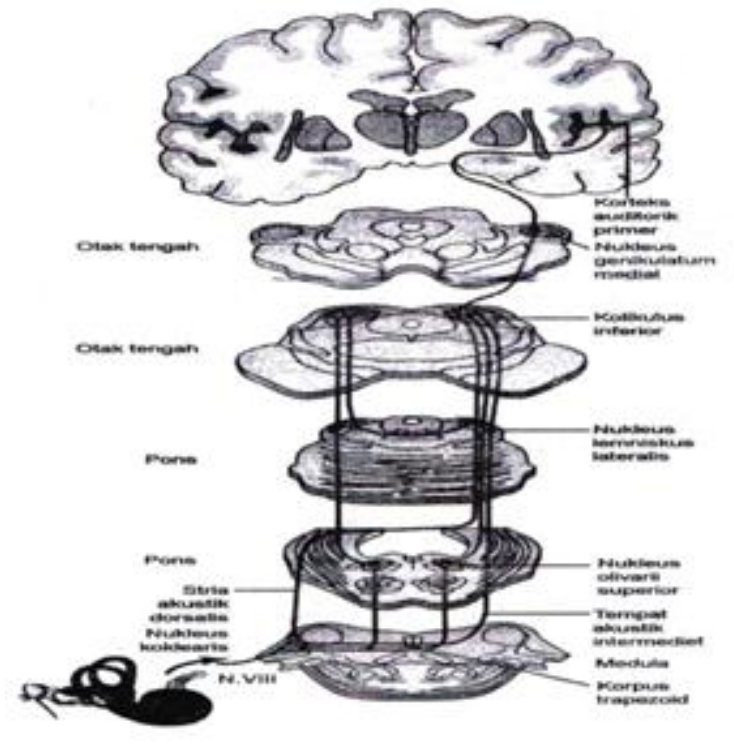

Gambar 1 Jaras saraf pendengaran

Dari korteks auditoris yang terdapat pada korteks serebri, jaras berlanjut ke hipotalamus. Hipotalamus merupakan daerah otak yang berfungsi sebagai pusat koordinasi sistem saraf otonom utama, yang kemudian mempengaruhi kelenjar eksokrin, salah satunya adalah kelenjar saliva. ${ }^{11}$

Musik yang dibentuk melalui tempo yang lambat, irama berulang dan kontur lembut akan memberikan suasana tenang dan santai. ${ }^{10}$ Saraf yang mendominasi pada keadaan tenang dan santai adalah sistem saraf parasimpatis yang mempersarafi kelenjar saliva. Rangsangan parasimpatis yang berperan dominan dalam sekresi saliva menyebabkan pengeluaran saliva encer dalam jumlah besar dan kaya enzim. Sekresi ini disertai oleh vasodilatasi hebat pada kelenjar, yang disebabkan oleh pelepasan lokal Vasoactive Intestinal Polypeptide (VIP). Polipeptida ini adalah kotransmiter asetilkolin pada sebagian neuron postganglionik parasimpatis. ${ }^{13,14}$

Digunakannya musik klasik barat pada penelitian ini, karena ada beberapa kelebihan yang terdapat dalam musik klasik barat ini sebagai media terapi. Musik klasik barat memiliki frekuensi nada dominan sedang sampai tinggi dan artikulasi yang jelas. Konsentrasi pikiran manusia lebih mudah terfokus pada musik instrumen yang memiliki frekuensi sedang (750-3000 $\mathrm{Hz})$ hingga tinggi $(3000-8000 \mathrm{~Hz})$ terlebih lagi apabila memiliki artikulasi musik yang jelas. ${ }^{15}$

Jumlah sekresi saliva cenderung meningkat melalui sistem saraf parasimpatis. Dinyatakan bahwa corticotrophin releasing hormone $(\mathrm{CRH})$ mengaktifkan sistem sympathetic-adrenal medullary. Dengan pemberian musik akan menghambat pelepasan CRH oleh hipotalamus, sehingga sistem saraf simpatis menjadi inaktif. Dapat disimpulkan bahwa peningkatan jumlah sekresi saliva karena sistem saraf simpatis menjadi inaktif. Peningkatan jumlah dan laju aliran saliva juga berhubungan dengan problem atau masalah dalam kesehatan rongga mulut serta stres psikologis. ${ }^{16}$

\section{SIMPULAN}

Hasil penelitian menunjukkan bahwa dengan mendengarkan musik klasik barat pada penderita xerostomia dapat meningkatkan sekresi saliva.

\section{DAFTAR PUSTAKA}

1. Lukisari $\mathrm{C}$ dan Kusharjanti. Xerostomia salah satu manifestasi oral diabetic; 2011. Available from: www.scribd.com. Accessed March,12.2011

2. Hasibuan S. Keluhan Mulut Kering Ditinjau dari Faktor Penyebab, Manifestasi dan Penanggulangannya; 2002. Available from: http://library.usu.ac.id. Accessed 11 November 2010

3. Sonis ST, Fazio RC, Fang L. Principles and Practice of Oral Medicine. Second Edition. Philadelphia: Saunders; 1995.

4. Nanci A. Oral Histology:Development, Structure, and Function. Philadelphia: Mosby; 2003.

5. Hasibuan S. Keluhan Mulut Kering Ditinjau dari Faktor Penyebab, Manifestasi dan Penanggulangannya; 2002. Available from: http://library.usu.ac.id. Accessed 11 November 2010

6. Turner MD dan Ship JA. Dry Mouth and Its Effects on the Oral Health of Elderly People. JADA. Vol.138. No.1; 2007.

7. Anggarini. BAB I Pendahuluan. Available from: http://repository.usu.ac.id; $2010 . \quad$ Accessed March,12.2011

8. Amerongen AVN. Ludah dan Kelenjar Ludah; Arti Bagi Kesehatan Gigi. Yogyakarta: Gadjah Mada University Press; 1992.

9. Bartels CL. Xerostomia-Information for Dentist, Helping Patients with Dry Mouth. Available from: http://www.oralcancerfoundation.org; 2005. Accessed November 11,2010

10. Hasegawa H, Uozumi T, Ono K. Physiological Evaluation of Music Effect for The Mental Workload. Available from: http://www.idemployee.id.tue.nl; 2004. Accessed 5 November 2010

11. Sherwood L. Fisiologi Manusia;dari Sel ke Sistem. Edisi 2. Jakarta;EGC; 2001.

12. Guyton AC dan Hall JE. Buku Ajar Fisiologi Kedokteran. Edisi 11. Jakarta: EGC; 2008.

13. Martini FH. Fundamental of Anatomy \& Phisiology. Seventh Edition. San Francisco: Pearson; 2006.

14. Ganong WF. Review of Medical Physiology, Ganong's. 23 ${ }^{\text {rd }}$ edition. New York: The McGrawHill Companies.Inc; 2010.

15. Campbell D. Efek Mozart. Jakarta: PT.Gramedia Pustaka Utama; 2002

16. Gomes NM, Katsurayama M, Makimoto FH, Santana LLO, Garcia EP, Becker MA, Santos MCD. Psychological Stress and Its Influence on Salivary Flow Rate, Total Protein Concentration and $\operatorname{Ig} A$, Ig $G$, and Ig $M$ Titers. NeuroImmunoModulation. Vol.17. No.6; 2010. 